\title{
Diel vertical migration of decapod larvae in the Portuguese coastal upwelling ecosystem: implications for offshore transport
}

\author{
Antonina dos Santos ${ }^{1, *}$, A. Miguel P. Santos ${ }^{1}$, David V. P. Conway ${ }^{2}$, Cátia Bartilotti ${ }^{1}$, \\ Patrícia Lourenço ${ }^{1,3}$, Henrique Queiroga ${ }^{3}$ \\ ${ }^{1}$ Instituto Nacional de Recursos Biológicos - IPIMAR, Av. Brasília, s/n, 1449-006 Lisboa, Portugal \\ ${ }^{2}$ Marine Biological Association of the United Kingdom, The Laboratory, Citadel Hill, Plymouth, PL1 2PB, UK \\ ${ }^{3}$ Departamento de Biologia, Centro de Estudos do Ambiente e do Mar, Universidade de Aveiro, 3810-193 Aveiro, Portugal
}

\begin{abstract}
The vertical distribution of decapod larvae off the northwest Portuguese coast was analysed in relation to associated environmental conditions from sampling during a $69 \mathrm{~h}$ period around a current meter mooring located on the shelf, approximately $21 \mathrm{~km}$ off the coast. Plankton samples were collected every $2 \mathrm{~h}$ at the surface with a neuston net and through the water column with a Longhurst Hardy Plankton Recorder (Pro-LHPR), allowing a very detailed resolution of larval vertical distribution. Environmental data (temperature, salinity, and chlorophyll a) were obtained every hour. To investigate the horizontal distribution of decapod larvae in relation to the coast, a plankton-sampling grid was carried out before the $69 \mathrm{~h}$ fixed station. Larvae of shelf decapod species were widely distributed over the shelf, while those of inshore species were found much closer to the coast. Decapod larvae (zoeae and megalopae) showed clear diel vertical migrations, only appearing in the upper $20 \mathrm{~m}$ at night, a migration that did not appear to be affected by physical conditions in the water column. Larval densities were highly variable, 0.01 to 215 ind. $\mathrm{m}^{-3}$ for zoeae and 0 to 93 ind. $\mathrm{m}^{-3}$ for megalopae, the zoeae being generally more abundant. The results indicated that during the day larvae accumulate very close to the bottom. The diel vertical migration behaviour is discussed as one of the contributing mechanisms for larval retention over the shelf, even with offshore transport conditions promoted by coastal upwelling, and is hence of major relevance for the recruitment success of decapod species that inhabit inshore and shelf zones of coastal upwelling systems.
\end{abstract}

KEY WORDS: Decapod larvae $\cdot$ Diel vertical distribution $\cdot$ Portuguese shelf $\cdot$ Transport processes

\section{INTRODUCTION}

Most studies on marine invertebrate larval ecology emphasise the importance of understanding dispersal processes because of their influence on recruitment and population dynamics (Connell 1985, Underwood \& Fairweather 1989). Transport processes during the larval phase are a critical component of the supply mechanism of larvae to habitats suitable for settlement and juvenile development (e.g. Botsford 1986). These processes also result in partition of time between different environments during the different stages of larval development, exposing the larvae to different mortality factors (Queiroga \& Blanton 2005).

Offshore studies focusing on spatial and temporal distribution of decapod larvae are rare (e.g. Lindley et al. 1994, Shanks \& Eckert 2005), with most studies carried out in estuaries and inner coastal zones (e.g. Garrison 1999, DiBacco et al. 2001). Physical processes such as upwelling, downwelling and other winddriven components of the circulation, internal waves and tidal bores, and density-driven flow have been 
proposed to explain variations in larval decapod supply rate (Shanks 1995, Queiroga \& Blanton 2005). Larval vertical distribution and migration of inshore decapod species when offshore, as well as of species inhabiting different zones of the shelf, are probably important in determining retention over the shelf and eventual recruitment, as has been shown for other invertebrate larvae (Shanks \& Brink 2005). Recent modelling studies on the Portuguese shelf (MartaAlmeida et al. 2006, Peliz et al. 2007) certainly indicate that larval decapod diel vertical migration between water masses moving in different directions at different depths may constitute a mechanism that contributes to their retention on the inner shelf near their release sites. Diel vertical migration behaviour has already been demonstrated for cirripede cyprids and sardine Sardina pilchardus larvae in the region (Santos et al. 2006, dos Santos et al. 2007).

The Ria Aveiro lagoon system and northern Portuguese offshore shelf region have recently been the focus of much work on the larvae of the shore crab Carcinus maenas. The first zoea and the megalopa developmental stages of this species are the only larval stages found inside the lagoon system (Queiroga et al. 1997), while the intermediate zoeae stages are found over the shelf (Queiroga 1996), a situation typical of many estuarine and inshore decapods. Vertical distribution studies on the larvae in the lagoon have shown vertical migration behaviour, particularly in relation to tidal cycles, that enhances the transport of the first zoea stage to the shelf (Queiroga et al. 1997) and the returning megalopae up the estuary (Queiroga 1998). Supply of megalopae to estuaries is thought to be partly controlled by the interaction of upwelling/downwelling circulation, driven by along-shore winds with the vertical position occupied by the larvae in the water column (Queiroga et al. 2006).

Available information indicates that larvae of virtually all decapod species perform some kind of diel vertical migration (Queiroga \& Blanton 2005). However, in most cases this evidence is indirect and comes from studies on horizontal patterns of distribution and abundance. Most studies addressing vertical migrations in shelf waters over time have used only neuston sampling or sampling at discrete depths (e.g. Shanks 1986, Abelló \& Guerao 1999) rather than high-resolution vertical sampling (Lindley 1986, Lindley et al. 1994).

The objective of the present study is to investigate the fine scale vertical distribution and migration behaviour of decapod larvae on the northern Portuguese shelf in relation to environmental conditions, to contribute to a better understanding of the processes that control larval supply to littoral and shelf populations in eastern boundary upwelling systems, as found off Western Iberia. We focused on Carcinus maenas larvae in particular detail, because their life history is better understood than any of the other species occurring in the area. Information on this species could help in the interpretation of the distribution and behaviour of the other species.

\section{MATERIALS AND METHODS}

Fieldwork. A research cruise was carried out aboard RV 'Noruega' from 9 to 22 May 2002 on the Portuguese shelf (Fig. 1). Just after the beginning of the cruise on 11 May 2002, a mooring - with 3 current meters (Aanderaa RCM 9), located at 5, 15 and $35 \mathrm{~m}$ depths, and 2 high-accuracy conductivity, temperature and pressure recorders (SBE MicroCats) - was deployed on the inner shelf at $40^{\circ} 45.9^{\prime} \mathrm{N} 08^{\circ} 59.0^{\prime} \mathrm{W}$, approximately $21 \mathrm{~km}$ offshore (Fig. 1). It was positioned at a bottom depth of $60 \mathrm{~m}$, in an area adjacent to the Aveiro coastal lagoon where decapod larvae were expected to be abundant, including Carcinus maenas larvae (Queiroga 1996). The mooring was recovered on 16 June 2002.

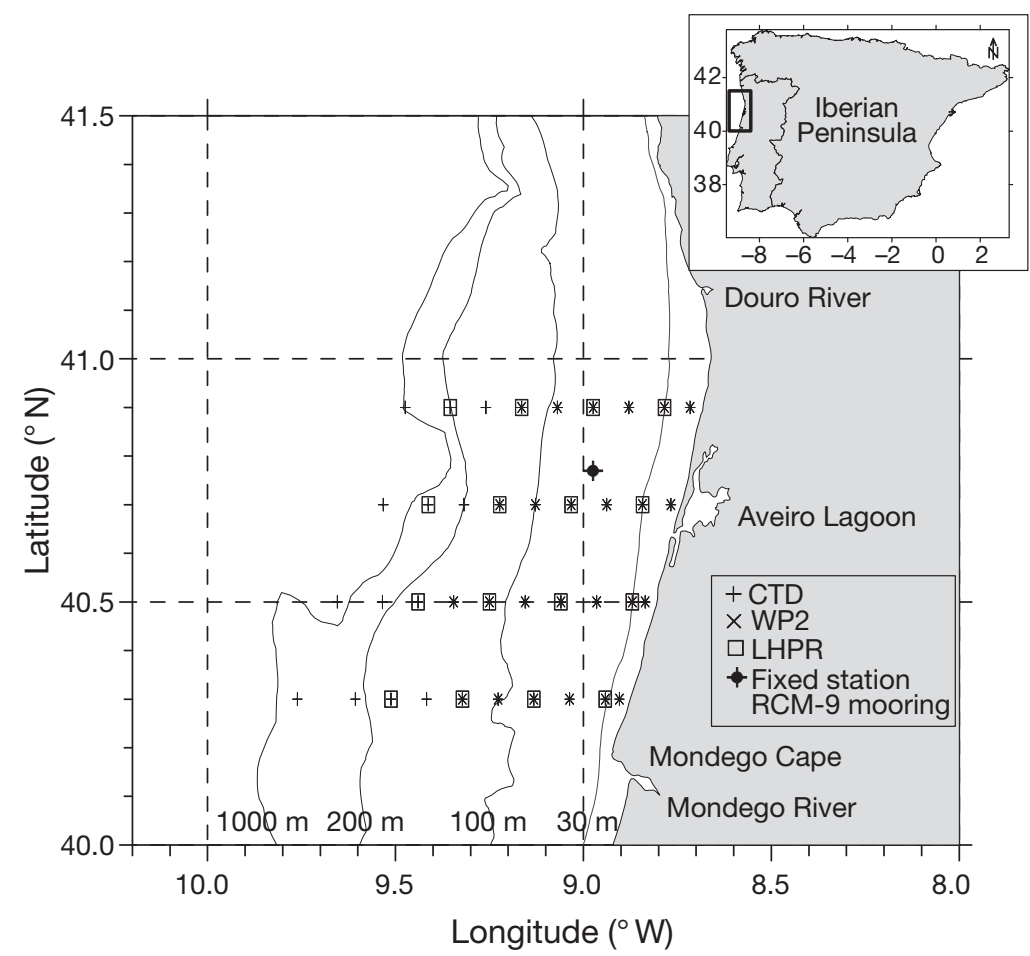

Fig. 1. Cruise stations and sampling details, 9 to 22 May 2002. CTD: conductivity, temperature, depth profiler; WP2: Working Party No. 2 plankton net; LHPR: Longhurst Hardy plankton recorder 
From 18 to 21 May 2002, the fixed current meter station position was sampled continuously for $69 \mathrm{~h}$. Temperature, salinity and chlorophyll a (chl a) concentration were measured every hour with a Seabird SBE 9 plus CTD (conductivity/temperature/depth) fitted with a Seapoint fluorometer. Depth-stratified zooplankton samples were collected every $2 \mathrm{~h}$ with a Pro-LHPR system, a commercially updated version of the Longhurst Hardy plankton recorder (Williams et al. 1983) to examine short timescale variability and detailed resolution of the vertical distribution of decapod larvae. The Pro-LHPR had a mouth opening of $0.42 \mathrm{~m}$ diameter and was fitted with a $280 \mu \mathrm{m}$ mesh net and towed at $\sim 4$ knots, sampling on oblique hauls from the surface to $10 \mathrm{~m}$ above the bottom. This system collects zooplankton between 2 rolls of $280 \mu \mathrm{m}$ filtering gauze. The gauze is advanced at operator specified time intervals inside a cod-end box to give, for each haul, a series of consecutive samples over the water column. The total sampling time for each haul was approximately $30 \mathrm{~min}$ and samples were collected at approximately $5 \mathrm{~m}$ depth intervals in the first $25 \mathrm{~m}$, then at $10 \mathrm{~m}$ depth intervals down to near bottom. Flow rate was monitored by a flowmeter mounted in the mouth aperture, and each sample represented approximately $25 \mathrm{~m}^{3}$ of water filtered. Neuston net samples were also collected every $2 \mathrm{~h}$. This net had a single rectangular mouth opening of $0.2 \times 1.0 \mathrm{~m}$, a net of $335 \mu \mathrm{m}$ mesh and a flowmeter mounted in the mouth aperture. It was towed horizontally for $3 \mathrm{~min}$ at a ship speed of $\sim 1.5$ knots, sampling the upper $20 \mathrm{~cm}$ of the water column.

To obtain environmental data for the region and decapod larval horizontal distribution and abundance, a grid of CTD casts and plankton sampling was carried out prior to the fixed-point sampling. This took place night and day from 15 to 17 May 2002 (60 h total duration) along 4 transects perpendicular to the coast. We used 2 different nets for plankton sampling, as indicated in Fig. 1: (1) a WP-2 (Working Party No. 2: UNESCO 1968) plankton net of $180 \mu \mathrm{m}$ mesh and $0.58 \mathrm{~m}$ mouth aperture, fitted with a calibrated flowmeter, towed obliquely between the surface and $10 \mathrm{~m}$ above the bottom; and (2) the Pro-LHPR system. The Pro-LHPR sampling was conducted over a wider area, but the WP-2 sampling was done at higher resolution. The distance between stations was $8 \mathrm{~km}$. The transect sampling is described in more detail in dos Santos et al. (2007).

Sample processing. All zooplankton samples were preserved in $\sim 4 \%$ borax-buffered formaldehyde, prepared using seawater. Samples were subsequently sorted for decapod larvae. The WP-2 net samples were only sorted for Carcinus maenas larvae, while all decapod larvae were identified in the grid and fixed-station
Pro-LHPR samples and in the fixed station neuston net samples. Decapod zoeae were identified to species level and developmental stage, whenever possible, using descriptions in dos Santos \& Lindley (2001) and dos Santos \& González-Gordillo (2004). Megalopae were identified to genus or to species level, whenever possible, using the descriptions in González-Gordillo et al. (2001). Data were standardized to ind. $\mathrm{m}^{-3}$ using flow information. Zooplankton biomass was estimated using displacement volume.

Statistical analysis. In order to examine temporal changes in the vertical distribution of decapod larvae at the fixed station, the instantaneous average depth of the larvae from the Pro-LHPR samples and the instantaneous abundance of larvae in the neuston layer were calculated. Average depth is a useful measure in representing the vertical distribution of the larvae through the water column (Pearre 2003).

The average depth of zoeae and megalopae for each sampling time was calculated as the weighted abundance of the larvae collected in each stratum $z$, at each sampling time $t$ :

$$
W M D_{t}=\frac{\sum_{z=1}^{9}\left(A_{z t} \times D_{z t}\right)}{\sum_{z=1}^{9} A_{z t}}
$$

where $W M D$ is the weighted mean depth of the larvae (m), $A$ is the abundance (ind. $\mathrm{m}^{-3}$ ), and $D$ is the average depth of each stratum (m) (Pearre 2003).

Also used in the time series analysis of the data was the depth of maximum chl a concentration, the total zooplankton biomass (expressed as biovolume) and physical information obtained from CTD casts, including depth of the thermocline, halocline and the 35.6 salinity value, which is used as a proxy of low salinity buoyant plumes in the region (Peliz et al. 2002). Wind velocity and solar radiation data from the meteorological station of the University of Aveiro were also used.

Data on zoeae and megalopae were always analysed separately. The $69 \mathrm{~h}$ fixed station sampling was analysed using time series techniques, which usually require a series with at least 4 relevant cycles (Chatfield 1996), but sampling had to be curtailed when just less than three $24 \mathrm{~h}$ cycles were completed because of the onset of bad weather. Because of this, standard time series analysis was used, backed up with ANOVA and correlations between variables based on data integrated through time, which effectively removed the serial correlations that were present in the data series.

In order to detect the periods of oscillation, time series on average abundance of the larvae along the water column, abundance of larvae in the neuston layer and average depth of larvae were autocorrelated, 
after removing the trend. Average depth and abundance in the neuston were also cross-correlated with the environmental variables. In most cases, the physical and the biological data were autocorrelated at a lag of $2 \mathrm{~h}$. Since this can increase the significance values of the cross-correlations, the data series were differentiated using a time lag of $2 \mathrm{~h}$ before the calculation. Because the factors that limit upward migration during the night and set the distribution at depth during the day are not necessarily the same, we calculated crosscorrelations separately for samples collected during the night and during the day, and also for the complete data series. The onset of day and night was delineated using sunrise and sunset times. The cross-correlation analyses were intended to test 2 key questions about the reaction of decapod larvae to changes in their physical environment: Do thermocline, halocline and the 35.6 salinity value constitute a barrier to upward migration at night? Does wind velocity and associated vertical mixing increase overall depth distribution of the larvae? The Bonferroni correction for multiple comparisons was used in all cases (Quinn \& Keough 2002).

Average abundance through the water column, aggregated within complete $24 \mathrm{~h}$ periods, was found not to be autocorrelated and was tested by ANOVA, using the day and night periods as the independent variable. Cochran tests indicated moderate heterogeneity of variances in the case of the megalopae, but since the significance of the test was lower than the significance of the diel effect, transformation of the variable was deemed unnecessary (Underwood 1997). Changes in the diel vertical distribution of larvae were investigated by averaging abundance by depth stratum across all sampling points and scaling abundance in each stratum by total abundance in the water column, separately for day and night. This procedure removes diel differences in overall abundance of larvae and allows comparison of depth distribution patterns. The diel difference in proportions of larvae in each depth stratum was found not to be autocorrelated over depth, and therefore, we used the Pearson correlation coefficient to relate it with depth. If larvae had essentially the same diel vertical distribution, then the differences should be randomly distributed and uncorrelated with depth.

Archive data. Following the cruise, additional data from the Instituto Nacional de Recursos Biológicos (IPIMAR) zooplankton database (A. dos Santos unpubl. data) on Carcinus maenas (green crab) and Atelecyclus rotundatus (circular crab) larvae were analysed to compare with the cruise data. These were from plankton samples taken on 24 plankton/oceanographic surveys carried out off Portugal between October 1986 and July 1990, initially taken to study sardine Sardina pilchardus spawning. The samples were taken with a $60 \mathrm{~cm}$ Bongo net of $305 \mu \mathrm{m}$ mesh, in oblique hauls from surface to near bottom, in 2 transects perpendicular to the coast $\left(41^{\circ} 05^{\prime} \mathrm{N}\right.$ with 6 stations and $40^{\circ} 05^{\prime} \mathrm{N}$ with 7 stations). The transects extended from 3 to $60 \mathrm{~km}$ off the coast.

\section{RESULTS}

\section{Environmental observations}

Coastal upwelling conditions occurred in the weeks preceding the survey. Several days before the fixed station was sampled there was a reversal of the wind direction, but this was not enough to significantly change the hydrographic patterns produced by the upwelling. During the fixed station sampling the wind reversed again to favour upwelling (Santos et al. 2006).

The CTD observations for the $69 \mathrm{~h}$ at the fixed station showed that, at this location, the depth of the thermocline oscillated between 10 and $20 \mathrm{~m}$, without any obvious trend. Salinity showed a subsurface minimum, also between 10 and $20 \mathrm{~m}$. During the first day of sampling, surface salinity values were $\sim 35.7$. However, after the second day, an intrusion of less saline waters $(<35.6)$ was observed in the upper 10 to $20 \mathrm{~m}$, probably advected from the north, as suggested by current

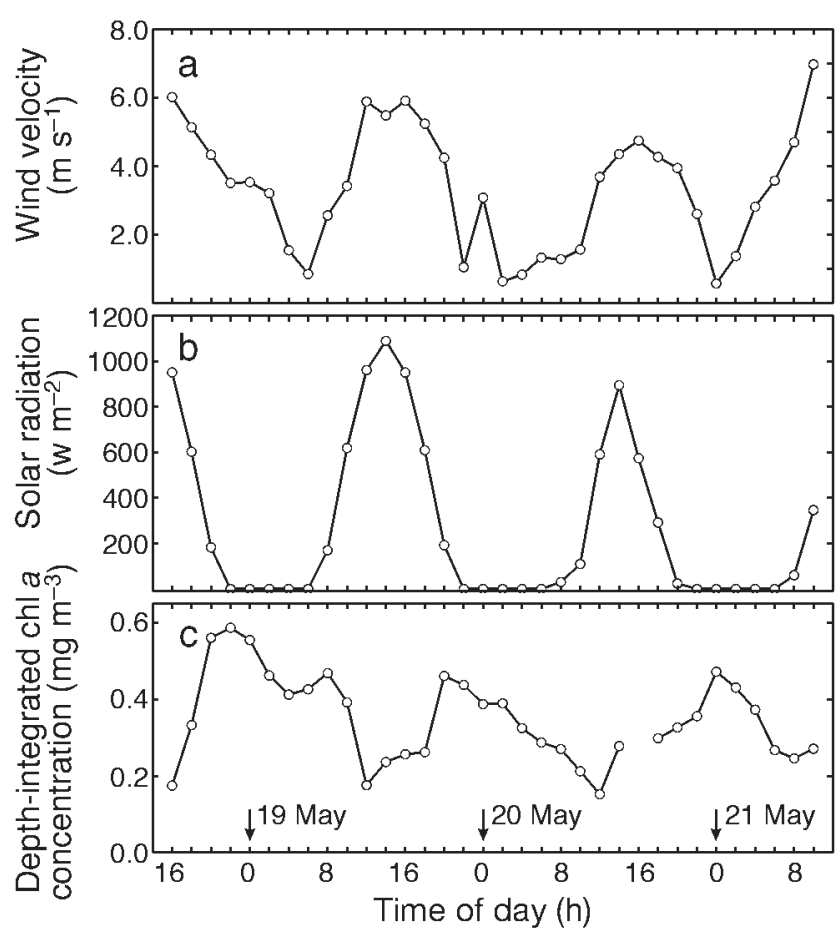

Fig. 2. (a) Wind speed, (b) solar radiation at the surface, and (c) depth-integrated average chl a during the $69 \mathrm{~h}$ fixed station study. Arrows indicate beginning of each day 
meter measurements (Santos et al. 2006). After the second day the thermocline and the halocline were largely coincident and the chl a maximum was between 20 and $40 \mathrm{~m}$.

Wind speed, solar radiation and depthintegrated chl a all showed cyclic diel variations at the fixed station (Fig. 2). During the first $48 \mathrm{~h}$ of the study, wind blew from the northwest, following the pattern typical of the wind regime of the Portuguese west coast, with low values during the night and early morning. Radiation and wind speed both peaked during the afternoon (Fig. 2a,b). The increases in wind speed during the afternoon of May 20 and during the early morning of May 21 were due to the passage of 2 cold fronts and were accompanied by a rotation to the southwest. Average chl a concentration over the water column peaked during the early night and decreased slowly through the night and morning (Fig. 2c).

\section{Decapod larvae horizontal distribution}

The horizontal distribution of total zoeae (Fig. 3a) showed that they were widely distributed over the shelf and in higher numbers than megalopae (Fig. 3b). Few zoeae were sampled at or beyond the $200 \mathrm{~m}$ contour on the 2 most northern transects or at most of the stations along the $30 \mathrm{~m}$ contour. Megalopae were most abundant between the 30 and $100 \mathrm{~m}$ contours. The most abundant larval species/genera in the area were Liocarcinus spp. (portunid crabs) (Fig. 3c), Atelecyclus rotundatus (Fig. 3d) and Anapagurus spp. (pagurid hermit crabs) (Fig. 3e). They all show a similar horizontal distribution to total zoeae, being more abundant between depths of 50 and $200 \mathrm{~m}$. A. rotundatus is a shelf species during its adult phase, while the genera $\mathrm{Li}$ ocarcinus and Anapagurus include species that can be both coastal and shelf when adults (Zariquiey-Álvarez 1968). The horizontal distributions of Necora puber (velvet swimming crab) and Carcinus maenas larvae, the most abundant representatives of coastal/estuarine species sampled, were also plotted for comparison (Fig. 3f,g). They showed a pronounced meridional distribution between the coast and the $30 \mathrm{~m}$ contour on the inner shelf, only occasionally being sampled further than $10 \mathrm{~km}$ from the coast. There were thus obvious distributional differences between the 2 categories of larvae plotted. N. puber and C. maenas were concentrated towards the coast and A. rotundatus and Liocarcinus spp. were widely distributed over the shelf.

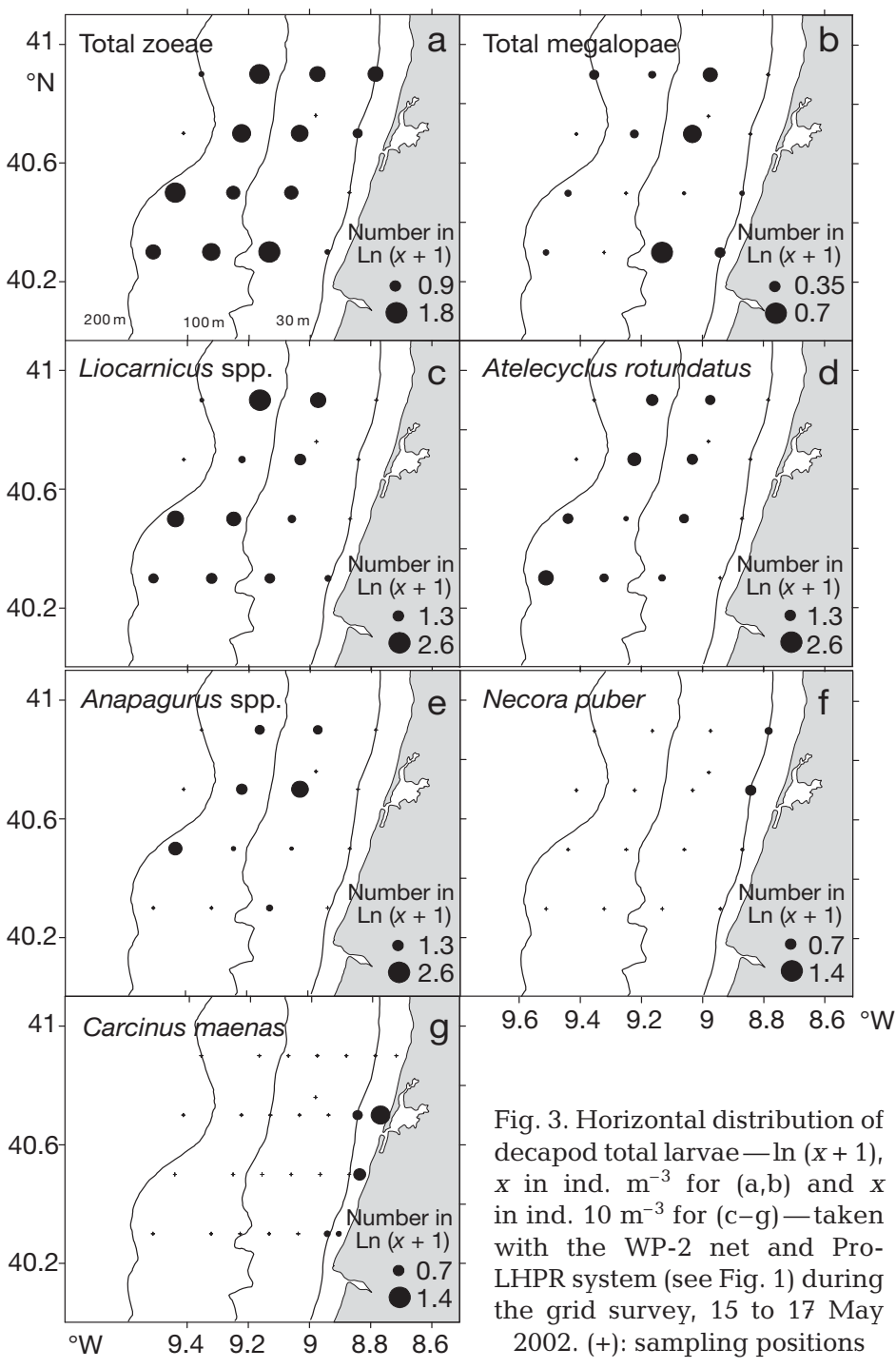

The archive data from the study area, examined subsequent to the cruise, also showed from a series of 24 previous surveys along 2 transects that while Carcinus maenas larvae were mainly distributed over the inner shelf, mostly within an area $10 \mathrm{~km}$ off the coast throughout the year (Table 1), Atelecyclus rotundatus zoeae, but not megalopae, were mainly distributed over the middle shelf in a band between 10 and $20 \mathrm{~km}$ off the coast.

\section{Decapod larval species composition at the fixed station}

The list of all decapod larval species, or genera, sampled at the fixed station is given in Table 2. Of the 61 categories, most were sampled in very low numbers. Of the total categories, 14 were not sampled in the Pro- 
Table 1. Archive data for Carcinus maenas (upper rows) and Atelecyclus rotundatus (lower rows and $\mathrm{ZV}$, in italics) larvae in the study area, separated into different distance zones from the coast. Percent (average concentration $\pm \mathrm{SD}$ in ind. $\mathrm{m}^{-3}$ ) of zoea $(\mathrm{Z})$ and megalopa $(\mathrm{M})$ stages over the whole area defined by the transects

\begin{tabular}{|lccc|}
\hline & $0-10 \mathrm{~km}$ & $10-20 \mathrm{~km}$ & $20-60 \mathrm{~km}$ \\
\hline ZI & $80(0.65 \pm 0.31)$ & $2(0.01 \pm 0.01)$ & $18(0.14 \pm 0.17)$ \\
& $43(0.49 \pm 0.34)$ & $48(0.54 \pm 0.66)$ & $9(0.09 \pm 0.04)$ \\
ZII & $79(0.15 \pm 0.21)$ & $8(0.01 \pm 0.004)$ & $13(0.02 \pm 0.0005)$ \\
& $15(0.11 \pm 0.08)$ & $55(0.39 \pm 0.34)$ & $30(0.21 \pm 0.22)$ \\
ZIII & $49(0.05 \pm 0.03)$ & $40(0.04 \pm 0.02)$ & $11(0.01 \pm 0.001)$ \\
& $11(0.06 \pm 0.03)$ & $60(0.35 \pm 0.39)$ & $29(0.16 \pm 0.1)$ \\
ZIV & $53(0.05 \pm 0.03)$ & $29(0.03 \pm 0.006)$ & $18(0.01 \pm 0.009)$ \\
& $5(0.03 \pm 0.002)$ & $75(0.41 \pm 0.45)$ & $20(0.1 \pm 0.06)$ \\
ZV & $2(0.01 \pm 0.005)$ & $81(0.61 \pm 0.79)$ & $17(0.12 \pm 0.12)$ \\
M & $89(0.07 \pm 0.05)$ & $11(0.008 \pm 0.00005)$ & - \\
& $37(0.05 \pm 0.03)$ & $32(0.04 \pm 0.06)$ & $31(0.04 \pm 0.03)$ \\
\hline
\end{tabular}

LHPR and 13 in the neuston net. Brachyuran larvae accounted for $54 \%$ of the total decapod larvae sampled and were mainly Liocarcinus spp., Atelecyclus rotundatus and Polybius henslowi (swimming crab). Anomuran (hermit crab) and caridean (shrimp) larvae each accounted for $19 \%$ of total larvae. The most abundant larval anomuran species were Anapagurus spp., Pisidia longicornis (longclawed porcelain crab) and Pagurus bernhardus (common hermit crab); the most abundant caridean species were Philocheras spp. (crangonid shrimps) Pandalina brevirostris (pandalid shrimp) and Processa spp. (processid shrimp). Megalopae represented about $21 \%$ of all decapod larvae sampled, the most abundant being Liocarcinus spp, Pilumnus spp. and Philocheras bispinosus comprising 47, 14 and $7 \%$ of megalopae, respectively.

Table 2. Mean abundance $\left( \pm \mathrm{SD}\right.$, ind $\left.\mathrm{m}^{-3}\right)$ of decapod larvae from the most abundant taxa collected with the Pro-LHPR (Longhurst Hardy plankton recorder) system and neuston net at the $69 \mathrm{~h}$ fixed station

\begin{tabular}{|c|c|c|c|c|c|}
\hline Taxa & Pro-LHPR & Neuston & Taxa & Pro-LHPR & Neuston \\
\hline BRACHYURA & & & Galathea squamifera & $0.009 \pm 0.03$ & $0.0003 \pm 0.001$ \\
\hline Liocarcinus spp. & $15.9 \pm 31.83$ & $10.56 \pm 25.1$ & & & \\
\hline Atelecyclus rotundatus & $5.16 \pm 15.97$ & $3.33 \pm 12.57$ & CARIDEA & & \\
\hline Polybius henslowi & $2.66 \pm 8.87$ & $1.92 \pm 7.07$ & Pandalina brevirostris & $1.37 \pm 1.4$ & $0.14 \pm 0.44$ \\
\hline Necora puber & $2.17 \pm 10.34$ & $1.48 \pm 8.19$ & Philocheras bispinosus & $1.25 \pm 1.84$ & $0.07 \pm 0.18$ \\
\hline Macropipus tuberculatus & $1.27 \pm 6.82$ & $0.97 \pm 5.46$ & Processa nouveli & $0.64 \pm 0.53$ & $0.04 \pm 0.11$ \\
\hline Thia scutellata & $1.01 \pm 2.18$ & $0.69 \pm 1.75$ & Eualus occultus & $0.59 \pm 0.69$ & $0.19 \pm 0.42$ \\
\hline Pilumnus spp. & $0.98 \pm 1.38$ & $0.49 \pm 0.95$ & Processa edulis & $0.09 \pm 0.13$ & $0.19 \pm 0.87$ \\
\hline Carcinus maenas & $0.65 \pm 1.23$ & $0.21 \pm 0.56$ & Palaemon serratus & $0.04 \pm 0.05$ & $0.11 \pm 0.21$ \\
\hline Ebalia sp. & $0.14 \pm 0.41$ & $0.07 \pm 0.21$ & Athanas nitescens & $0.04 \pm 0.06$ & $0.03 \pm 0.12$ \\
\hline Eurynome sp. & $0.07 \pm 0.11$ & $0.04 \pm 0.1$ & Philocheras trispinosus & $0.04 \pm 0.08$ & $0.005 \pm 0.02$ \\
\hline Pirimela denticulata & $0.04 \pm 0.07$ & $0.39 \pm 1.29$ & Processa modica & $0.02 \pm 0.06$ & $0.002 \pm 0.008$ \\
\hline Xantho incisus & $0.03 \pm 0.12$ & $0.02 \pm 0.09$ & Alpheus glaber & $0.01 \pm 0.04$ & $0.16 \pm 0.88$ \\
\hline Brachynotus sexdentatus & $0.006 \pm 0.02$ & & Dichelopandalus bonnieri & $0.01 \pm 0.03$ & \\
\hline Inachus sp. & $0.003 \pm 0.01$ & & Processa canaliculata & $0.008 \pm 0.03$ & $0.0005 \pm 0.003$ \\
\hline Parthenope sp. & $0.001 \pm 0.006$ & & Philocheras sculptus & $0.007 \pm 0.02$ & \\
\hline Pinnotheres pisum & $0.0008 \pm 0.004$ & & Caridion steveni & $0.005 \pm 0.02$ & \\
\hline Portumnus latipes & & $0.02 \pm 0.06$ & Crangon crangon & $0.003 \pm 0.01$ & $0.05 \pm 0.2$ \\
\hline Monodaeus couchii & & $0.01 \pm 0.06$ & Periclimenes sagittifer & $0.003 \pm 0.01$ & \\
\hline Pachygrapsus marmoratus & & $0.002 \pm 0.01$ & Lysmata seticaudata & $0.002 \pm 0.01$ & \\
\hline Xantho pilipes & & $0.001 \pm 0.007$ & Thoralus sp. & $0.002 \pm 0.008$ & \\
\hline Cancer pagurus & & $0.001 \pm 0.007$ & Palaemon elegans & & $0.04 \pm 0.25$ \\
\hline Rochinia carpenteri & & $0.0006 \pm 0.003$ & Palaemon longirostris & & $0.01 \pm 0.01$ \\
\hline Geryon sp. & & $0.0004 \pm 0.002$ & Processa sp. & & $0.006 \pm 0.03$ \\
\hline \multirow[t]{2}{*}{ Goneplax rhomboides } & & $0.0004 \pm 0.002$ & Palaemon adspersus & & $0.002 \pm 0.01$ \\
\hline & & & Hippolyte sp. & & $0.0006 \pm 0.003$ \\
\hline ANOMURA & & & Philocheras echinulatus & & $0.0005 \pm 0.003$ \\
\hline Anapagurus spp. & $3.9 \pm 5.53$ & $1.44 \pm 2.98$ & & & \\
\hline Pisidia longicornis & $1.65 \pm 2.71$ & $0.24 \pm 0.8$ & OTHER GROUPS & & \\
\hline Pagurus bernhardus & $0.89 \pm 0.97$ & $0.006 \pm 0.02$ & Upogebia spp. & $0.76 \pm 0.48$ & $0.03 \pm 0.1$ \\
\hline Galathea dispersa & $0.43 \pm 0.61$ & $0.16 \pm 0.29$ & Solenocera membranacea & $0.04 \pm 0.07$ & $0.002 \pm 0.008$ \\
\hline Pagurus spp. & $0.13 \pm 0.43$ & $0.03 \pm 0.03$ & Callianassa subterranea & $0.03 \pm 0.05$ & $0.0005 \pm 0.003$ \\
\hline Galathea nexa & $0.07 \pm 0.09$ & & Scyllarus arctus & $0.009 \pm 0.02$ & \\
\hline Diogenes pugilator & $0.01 \pm 0.03$ & $0.0005 \pm 0.003$ & Jaxea nocturna & $0.007 \pm 0.02$ & \\
\hline
\end{tabular}




\section{Vertical distribution and diurnal migration}

To examine the comparative vertical distribution of inshore and shelf decapod larvae, the mean vertical distributions, averaged over the $3 \mathrm{~d}$ at the fixed station for each sampling time and depth interval, are given for Carcinus maenas and the 3 most abundant larvae, Liocarcinus spp., Atelecyclus rotundatus and Anapagurus spp. (Fig. 4). C. maenas was the only inshore species in high enough numbers to plot. Because numbers of larvae were variable over time and between species/genera, they were plotted as percentages to facilitate comparison. All species showed a very similar pattern of diel vertical distribution, generally being deeper in the water column during the day, migrating towards the surface and into the neuston layer at night, and returning to deeper water before or following dawn. There was no clear difference between the behaviour of $C$. maenas and the larvae of shelf species.

As the diel vertical distributions of the most abundant inshore and shelf decapod species/genera larvae at the fixed station appeared to be similar, the diel depth distribution of total decapod zoeae and total megalopae were similarly plotted (Fig. 5) to examine the vertical distribution of the entire decapod larval population.

Densities of zoeae were highly variable, from 0.01 to 215 ind. $\mathrm{m}^{-3}$. Below $20 \mathrm{~m}$, there was no marked diel difference in numbers sampled (Fig. 5a). From 16:00 to 20:00 $\mathrm{h}$, in the period prior to night, their distribution was almost bimodal, with some of the lowest numbers in the intermediate depths. Between 22:00 and 02:00 h, during the first period of the night, numbers increased considerably in the upper $20 \mathrm{~m}$, especially in the neuston layer. In the remaining night period up to 06:00 $\mathrm{h}$, numbers in the 0 to $20 \mathrm{~m}$ depth layers gradually decreased and zoeae moved out of the neuston layer. Following dawn, between 08:00 and 14:00 h, zoeae numbers reduced further and highest numbers were deeper in the water column.

Megalopae were sampled in lower numbers than zoeae (from 0 to 93 ind. $\mathrm{m}^{-3}$ ), but showed essentially the same vertical distribution. In the period prior to night, numbers were generally low over the whole water column, with some of the highest numbers below $35 \mathrm{~m}$ and a bimodal distribution. Numbers gradually increased in the upper $35 \mathrm{~m}$ at night until 02:00 $\mathrm{h}$, especially in the neuston layer and then decreased rapidly before dawn. On return to daylight, from 08:00 to $14: 00 \mathrm{~h}$, numbers gradually increased towards the bottom.

More larvae were generally collected during the night than during the day; 3 and 8 times higher for zoeae and megalopae, respectively. Megalopae showed a more pronounced diel difference in numbers
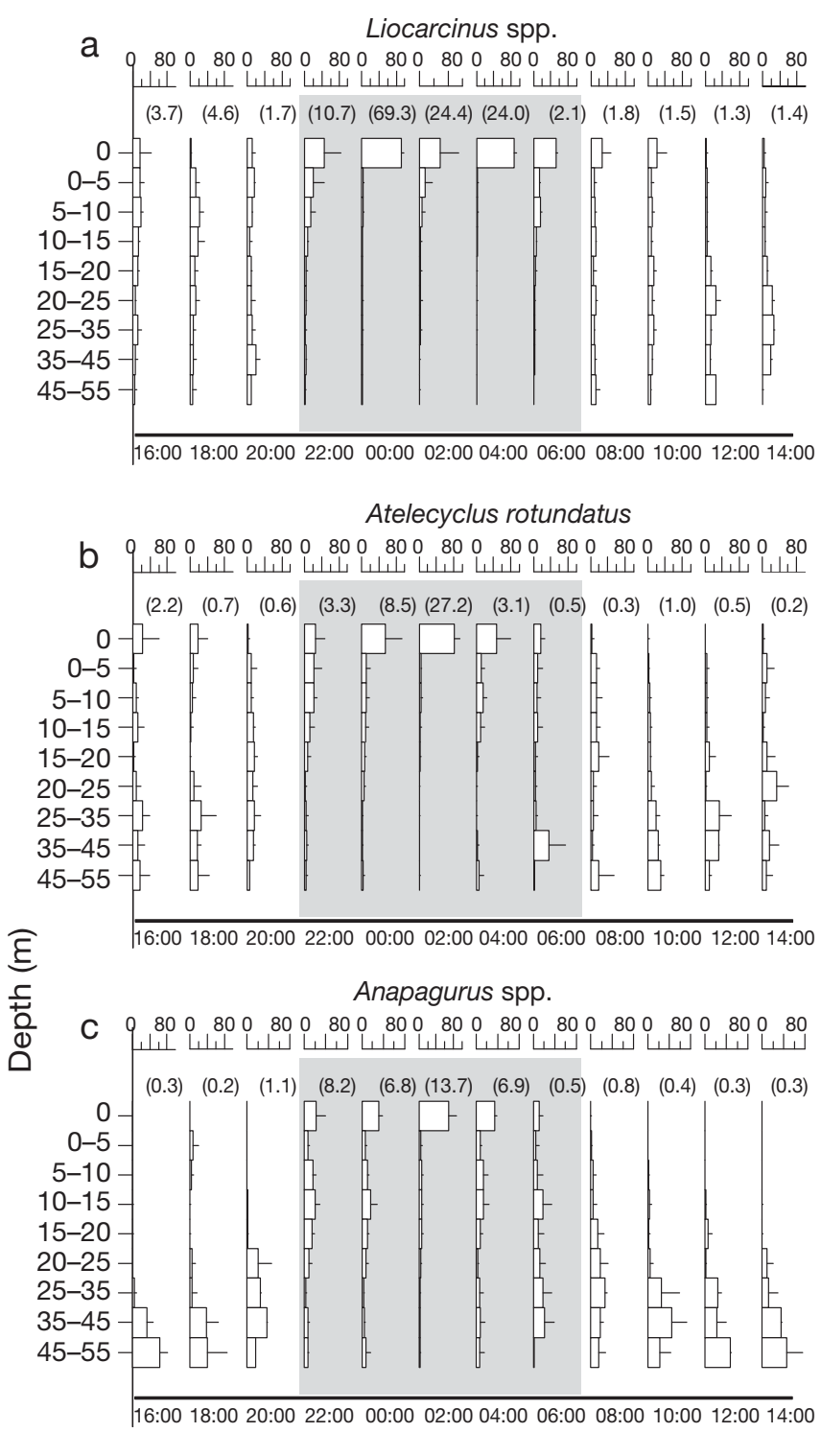

Carcinus maenas

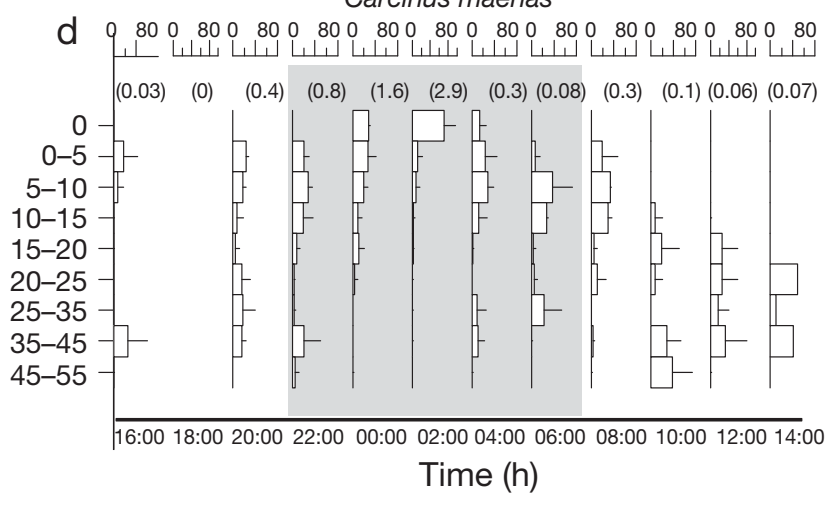

Fig. 4. Vertical distribution of the most abundant decapod larval species (as percentage of total numbers $\pm \mathrm{SE}$ ) from the Pro-Longhurst Hardy plankton recorder and neuston hauls at the $69 \mathrm{~h}$ fixed station, averaged over the $3 \mathrm{~d}$. ( $\square$ ): night period. Numbers in brackets are average abundance in ind. $\mathrm{m}^{-3}$ for the entire water column at each sampling time 
sampled at all depths (Fig. 5b), many more being sampled at night compared to the zoeae. These diel differences were significant, both for zoeae and megalopae (zoeae: $F_{\mathrm{s}}=10.850, \mathrm{df}=1, \mathrm{p}<0.05$; megalopae: $\left.F_{\mathrm{S}}=12.529, \mathrm{df}=1, \mathrm{p}<0.05\right)$.

The diel difference in proportions of larvae, aggregated across sampling times, was not significantly correlated with depth in the case of the zoeae $(\mathrm{r}=0.55$, $\mathrm{df}=7, \mathrm{p}>0.10)$, but was with the megalopae $(\mathrm{r}=0.72$, $\mathrm{df}=7, \mathrm{p}<0.05)$. Proportionally fewer megalopae were collected above $20 \mathrm{~m}$ and more below $20 \mathrm{~m}$ during the day than at night. The zoeae, despite a non-significant correlation, were proportionally more abundant during the night in the neuston layer and always more abundant during the day in the other depth strata.

Average abundance, abundance in the neuston and average depth of zoeae and megalopae are given in Fig. 6, which consistently shows higher values of abundance and a shallower distribution during the night. Autocorrelation values (Fig. 7) were always positive at a time lag of $24 \mathrm{~h}$, and negative at time lags between 8 and $18 \mathrm{~h}$.

\section{Vertical distribution of larvae in relation to environmental variables}

During the day, the average depth distribution and abundance of zoeae were positively correlated with wind velocity $(\mathrm{r}=$ 0.595, $\mathrm{p}<0.05$ ), but not with zooplankton biovolume, chl a or solar radiation. During the night, average depth of the zoeae and abundance of zoeae and megalopae were not correlated with any of the variables. When the complete data series was tested, only wind speed was positively correlated with average depth of the zoeae $(r=0.541$, $\mathrm{p}<0.05)$.

\section{Transport, retention and diel vertical migration}

Larval drift was simulated using the current meter mooring data and the diel vertical migration pattern observed. Results showed that larvae stay in the Ekman surface layer during the night ( $21: 30 \mathrm{~h}$ to $06: 30 \mathrm{~h}$ ), migrate to the bottom at 'dawn' (06:30 to 07:30 h), stay in the bottom Ekman layer during the day $(07: 30$ to $20: 30 \mathrm{~h})$, and migrate to the surface at 'dusk' (20:30 to $21: 30 \mathrm{~h})$. It was considered that average transport was nil during both migrations (dawn and dusk).
The advection in the Ekman surface layer was calculated using the speed and direction data from the current meter located at $15 \mathrm{~m}$ depth. Considering that the $35 \mathrm{~m}$ current meter measured the interior flow field not affected by the Ekman layers, advection at the bottom was calculated applying a simple parameterisation (correction) to obtain an estimation of the speed and direction in the Ekman bottom layer. The correction was calculated considering that the shelf is weakly stratified at this time of the year and, with a viscosity of $0.02 \mathrm{~m}^{2} \mathrm{~s}^{-1}$, the speed of the $35 \mathrm{~m}$ current meter is reduced, on average, to about half and the direction about $30^{\circ}$ to the left (A. Peliz pers. comm.). Based on this information, a progressive vector diagram, which is a way to simulate a Lagrangian display from Eulerian measurements, was computed for the period 11 May to 15 June 2002 (Fig. 8).

It is clear from Fig. 8 that the main component of the transport is alongshore and very little offshore advection occurs. In the first days there is a northward advection with downwelling conditions until about

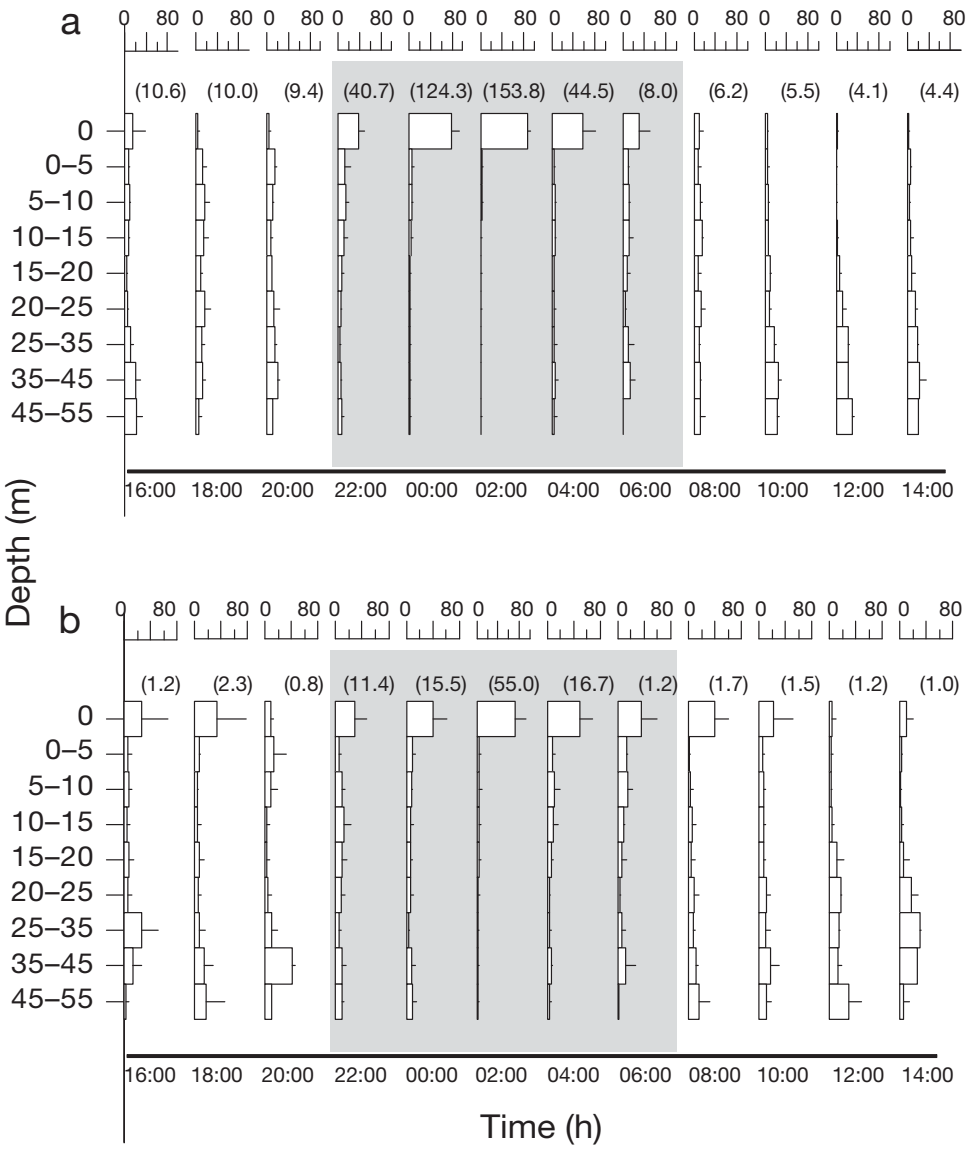

Fig. 5. Vertical distribution of (a) total decapod zoeae and (b) total megalopae (as percentage of total numbers \pm SE) from the Pro-Longhorst Hardy plankton recorder and neuston hauls at the $69 \mathrm{~h}$ fixed station, averaged over the $3 \mathrm{~d}$. ( $\square$ ): night period. Numbers in brackets are average abundance in ind. $\mathrm{m}^{-3}$ for the entire water column at each sampling time 

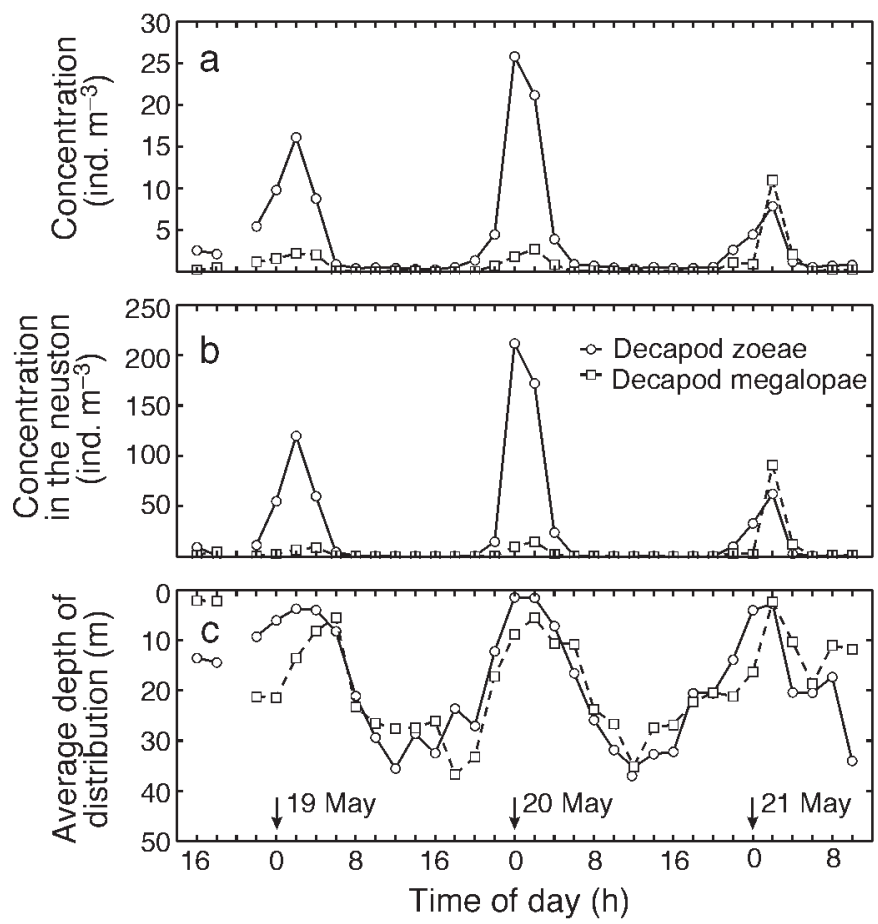

Fig. 6. (a) Integrated abundance in the water column, (b) abundance in the neuston and (c) average depth distribution of decapod zoeae and megalopae from the $69 \mathrm{~h}$ fixed station sampling. Arrows indicate beginning of each day

18 May 2002. Following this there is a reversal of the wind direction to favour upwelling, when the advection is almost entirely equatorwards, a situation that generally persisted until the end of the current meter measurements on 15 May 2002. Thus, even with upwelling-favourable conditions for almost 1 mo,

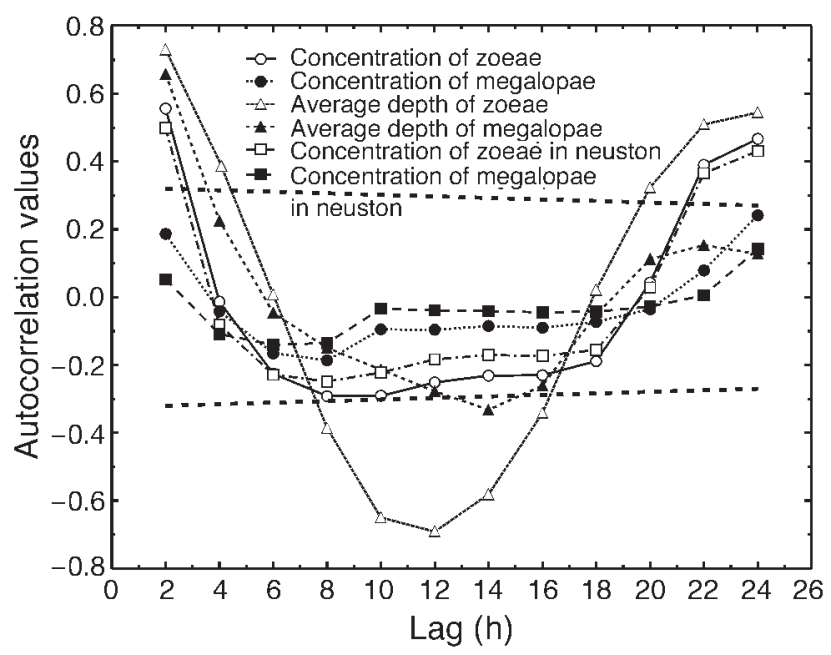

Fig. 7. Autocorrelation values for integrated abundance in the water column, abundance in the neuston and average depth distribution of decapod zoeae and megalopae during the $69 \mathrm{~h}$ station study. (-----): $5 \%$ significance level
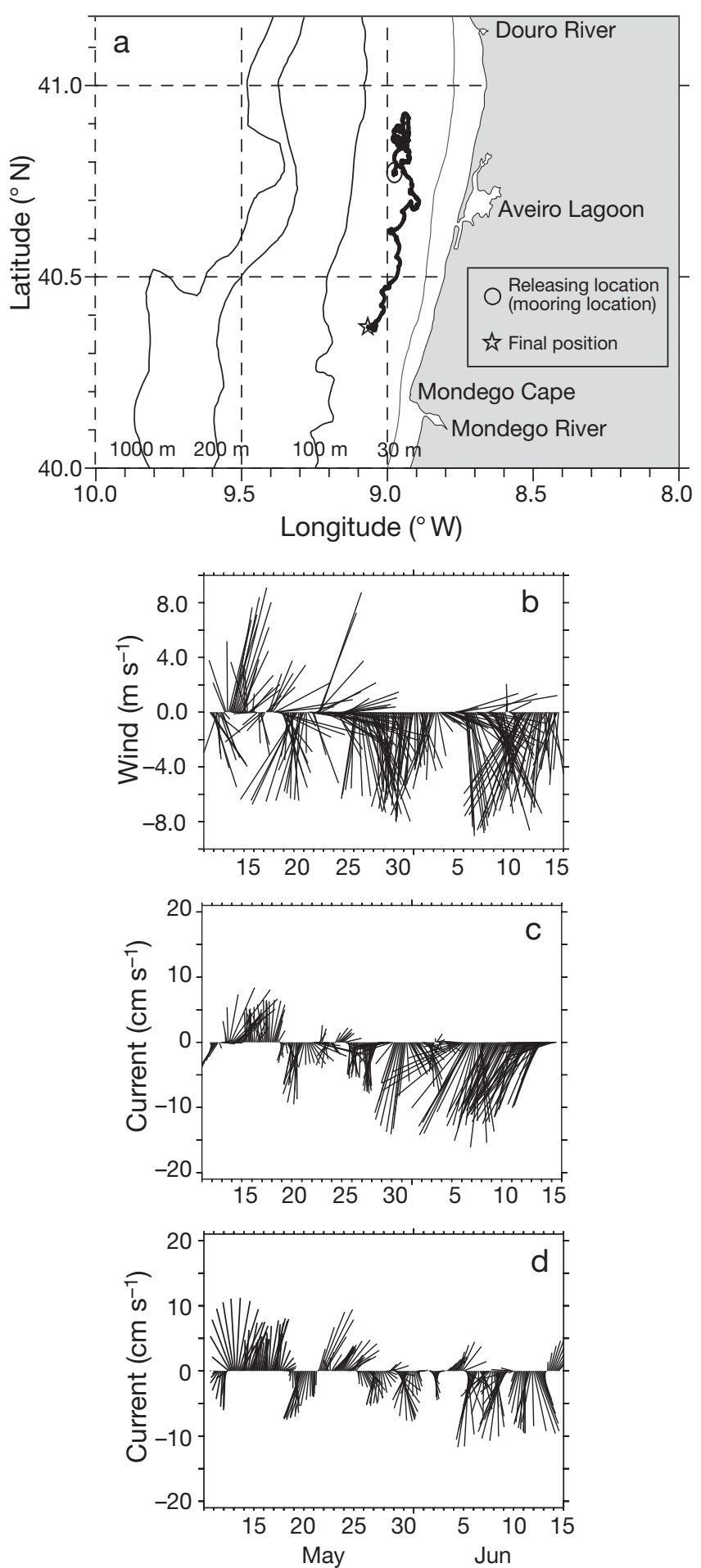

Fig. 8. (a) Progressive vector diagram that simulates larval drift based on their diel vertical migration behaviour. Stick diagrams of (b) wind measured by the Portuguese Meteorological Office (IM) at Cape Carvoeiro $\left(39^{\circ} 21.6^{\prime} \mathrm{N}, 09^{\circ} 24.0^{\prime} \mathrm{W}\right)$ and $(\mathrm{c}, \mathrm{d})$ current meter data at (c) $15 \mathrm{~m}$ and (d) $35 \mathrm{~m}$ (see 'Materials and methods' for a more detailed explanation). (O): larval release point (corresponding to the location of the current meter mooring array); (t) final location of larvae after about 1 mo of simulation 
cross-shelf dispersal of vertically migrating larvae was highly reduced, and the net result is retention with a meridional distribution over the shelf.

\section{DISCUSSION}

Species analysis of the decapod larvae from the LHPR and neuston net samples taken at the fixed station indicated high species diversity, with 61 species/genera recorded, typical of the region (dos Santos 1999). Some only occurred in one or the other of the nets, but this was probably a reflection of the low numbers sampled, rather than a true indication that they were restricted to the neuston layer, or to deeper in the water column. Brachyuran larvae dominated in the samples, comprising $54 \%$ of total decapod larvae, a proportion normal for northern European waters (e.g. Lindley et al. 1994) and for the Portuguese shelf (dos Santos 1999).

Horizontal distributions clearly showed a pattern related to their presumed settlement areas. The inshore species, Carcinus maenas and Necora puber, were concentrated towards the coast, while the shelf species were widely distributed. The distribution of C. maenas larvae was of particular interest, due to its socio-economical importance in the region of the Aveiro Lagoon and previous knowledge on their ecology inside this system (Queiroga et al. 1997). These larvae were expected to be abundant in the region of the fixed station, based on data from a previous cruise (Queiroga 1996), in which zoeal stages, other than the first zoeae, were found over the middle shelf, further offshore than in the present study. However, that cruise may have been in an exceptional period, as the present cruise distributional data and also the archive data showed that the fixed station was located just outside their normal main distribution.

The most abundant taxa were Liocarcinus spp., which includes species such as $L$. depurator, $L$. arcuatus and L. marmoreus that occur both inshore and over the shelf. All are common in Portuguese waters (Zariquiey-Álvarez 1968), but as they could not be speciated only a general distribution pattern was obtained. Larvae belonging to species that must return to the coast for settlement, such as Carcinus maenas, Necora puber, Pisidia longicornis and Diogenes pugilator, were rare at the fixed station, and their horizontal distribution showed that they were mainly restricted to a $10 \mathrm{~km}$-wide band along the coast, over bottom depths less than $30 \mathrm{~m}$. This result is similar to that obtained by Shanks \& Eckert (2005), who analysed the distribution of larvae from coastal and shelf species from the California upwelling system and concluded that larvae belonging to inshore species are mainly located within $20 \mathrm{~km}$ of the shore.
Diel abundance of decapod larvae was statistically different, there being many more sampled at night, especially in the neuston layer. This could indicate net avoidance, as has been shown for other zooplankton species using different nets (Stehle et al. 2007). However, Lindley et al. (1994), using similar LHPR equipment, concluded that there was no clear evidence for avoidance by decapod larvae. The neuston net was towed at $\sim 1.5$ knots $\left(0.77 \mathrm{~m} \mathrm{~s}^{-1}\right)$, less than half the speed of the Pro-LHPR $;$ therefore, some avoidance during the day is possible, especially by the more motile brachyuran megalopae. However, considering the size and swimming ability of decapod larvae (Mileikovsky 1973, Chia et al. 1984), avoidance would be unlikely to be a problem with either net. Therefore, our results suggest that during the day, both zoeae and megalopae larvae will be in the narrow layer close to the bottom that, for equipment safety reasons, was not sampled by the Pro-LHPR. This deep distribution has been shown to occur with Pandalus jordani early juveniles stages off the central Oregon coast (USA) (Rothlisberg \& Pearcy 1977).

The Portuguese shelf has a complex hydrography, coastal upwelling events occurring periodically during spring and summer, as they did before the cruise and during the sampling at the fixed station. This upwelling, in conjunction with the Western Iberian Buoyant Plume (WIBP) and the slope circulation associated with the Iberian Poleward Current (IPC) (Peliz et al. 2002, Santos et al. 2004) will influence the dispersal of decapod larvae over the shelf. The WIBP appears to be present all year round off NW Iberia (Peliz et al. 2002, Santos et al. 2004, 2006), changing the buoyancy and stratification of the shelf water column and, consequently, the surface Ekman layer transport and inner shelf circulation. In the case of a well-developed WIBP, the transport, in the surface layers would be mainly offshore during upwelling. However, the presence of the IPC could create a blocking effect to this offshore transport, and the interactions with the WIBP generate a convergence zone at the shelf break and a mechanism of larval retention over the shelf (Santos et al. 2004).

Inshore decapod larvae exported from the Aveiro lagoon system, developing on the inner Portuguese shelf, should experience greater alongshore than cross-shelf transport, as suggested by a modelling study (Peliz et al. 2007). As a result, these larvae should be distributed in the inner and middle shelf in patches parallel to the coast, related to the intermittency of downwelling and upwelling events, the associated alongshore circulation and the presence of buoyant plumes in the area. This is exactly the distribution observed in the current study for Carcinus maenas and Necora puber, also predicted by the larval drift calcu- 
lations based on the current meter data (Fig. 8). Similar distributions were previously reported for cirripede cyprids (dos Santos et al. 2007), although in a more offshore position, and are considered a common event, controlled by the inner shelf circulation (Epifanio \& Garvine 2001).

Larval dispersal due to shelf hydrography depends greatly on their vertical distribution and time spent in different water layers, so the capacity to perform diel vertical migrations will be a crucial factor. Decapod larvae, both of inshore and shelf species, showed conventional diel vertical migrations, the majority appearing in the surface layers at night, returning to deeper water during the day. This behaviour is similar to that found for decapod larvae in the North and Celtic Seas (Lindley et al. 1994) and may contribute to their retention on the shelf during upwelling conditions. Results from a modelling study on the retention of larval Carcinus maenas off Western Iberia (MartaAlmeida et al. 2006), indicated that there would be high dispersal in the absence of diel vertical migration. By partitioning the time between a surface layer moving seaward and a bottom layer where the compensating counter-current develops, larvae avoid seaward dispersal (Peterson 1998). Physical and biological gradients in the water column have been shown to alter vertical migration in cirripede larvae in the study area (dos Santos et al. 2007) and decapod larvae in other areas (e.g. Hobbs \& Botsford 1992, Lindley et al. 1994, Wing et al. 1998). However, the only factor measured which appeared to modify decapod larval vertical distribution in the present study was an increase in wind speed that resulted in zoeae having a deeper average depth distribution. This may have been due to an active migration to avoid turbulence, or a passive re-distribution due to a higher mixing depth.

Another suggested mechanism for transporting inshore decapod megalopa larvae to the coast is by internal waves acting on the surface layer (Shanks 1985). However, the study was based on neuston sampling only and requires that for transport to be accomplished, megalopae should be neustonic and not perform diel vertical migrations. Based on the results of the present study, this mechanism would not operate, as megalopae spent more time close to the bottom, where if they remained they would be transported inshore in the Ekman bottom layer during upwelling events. However, their diel vertical migration away from the bottom would maintain their position around the same location, or take them a little further inshore.

Nevertheless, offshore transport is not a problem for larvae migrating over the middle shelf, as this group was composed of larvae whose adults mainly inhabit the shelf and their megalopae can settle anywhere over the shelf. Tapia et al. (2004) suggested that larval supply to shore habitats could be associated with daily sea breezes that can produce short-term, strong onshore surface currents. However, megalopae would need to be at the surface during the morning hours and although around $28 \%$ were at the surface between the 06:00 and 10:00 $\mathrm{h}$, more were present $(48 \%)$ at night from 22:00 to 04:00 h, so only a small proportion would benefit from this mechanism.

Off the Portuguese coast, retention of decapod larvae in inshore waters is probably determined by intensification and relaxation of upwelling-favourable winds, which have pulses of $\sim 7$ to $10 \mathrm{~d}$ (dos Santos et al. 2007). In inshore waters (depths less than $30 \mathrm{~m}$ ) surface and bottom layers tend to overlap, reducing cross-shelf transport (Peterson 1998), thus diel vertical migration will not be an advantage for larval retention. However, the intermittency of upwelling/downwelling events could be an important mechanism to retain decapod larvae inshore as was showed for bivalve larvae off California (Shanks \& Brink 2005).

The modelling of Peliz et al. (2007) predicts that decapod larvae will be distributed alongshore over the middle shelf as a consequence of the upwelling system dynamics. This appears to be true for decapod larvae belonging to shelf species and also for larvae with a distribution on the inner shelf and for some other crustacean larvae inhabiting the area (dos Santos et al. 2007). The other model (Marta-Almeida et al. 2006) predicts that larvae performing diurnal vertical migration and subjected to upwelling conditions will be retained on the shelf during their development, which is also supported by our data. However, the larval drift simulation (Fig. 8) indicates that Carcinus maenas zoea found at the fixed station (21 $\mathrm{km}$ offshore), and any other shore or estuarine decapod larval species that has been carried to the middle shelf, would not reach the coast within a realistic time to settle. C. maenas megalopae has only 12 to $17 \mathrm{~d}$ duration at 12.5 to $18^{\circ} \mathrm{C}$ (Dawirs 1985) so only those larvae retained in the inner shelf zone, as a large proportion appear to be, would be able to settle and recruit. Therefore, the numbers of estuarine and coastal decapod larvae recruiting each year will depend on the interannual differences in hydrographic conditions and the varying distances they are carried from the coast.

Once inshore and estuarine larvae are over the inner shelf they may be able to detect specific cues indicating they are close to the coast and take actions to bring them to their settlement areas, for example changing their migratory behaviour to synchronise with tides (Queiroga et al. 2006). In support of this, it has been observed that some decapod larvae, reared under laboratory conditions, only metamorphose in the presence of settlement cues (Forward et al. 1994, dos Santos et 
al. 2004), and that megalopae of estuarine species show different swimming behaviours in the presence of estuarine and oceanic waters (Forward \& Rittschof 1994). However, confirmation of this will require further investigations in the coastal zone.

Acknowledgements. This study was supported by Fundação para a Ciência e Tecnologia (FCT), under the Support Community Framework III, Operational Programme Science, Technology and Innovation, which funded the research project 'Pro-Recruit - Shelf processes controlling recruitment to littoral populations in an eastern oceanic boundary: using barnacles and crabs as models' (POCTI/1999/BSE/36663). Many thanks are due to F. Quintela, to all crew members and technicians on the 2002 Pro-Recruit survey and to Á. Peliz for his help and discussions on the larval drift calculations. This is a contribution to GLOBEC and EUR-OCEANS (EC FP6 No. E 511106).

\section{LITERATURE CITED}

Abelló P, Guerao G (1999) Temporal variability in the vertical and mesoscale spatial distribution of crab megalopae (Crustacea: Decapoda) in the Northwestern Mediterranean. Estuar Coast Shelf Sci 49:129-139

Botsford LW (1986) Effects of environmental forcing on agestructured populations. Northern California Dungeness crab (Cancer magister) as an example. Can J Fish Aquat Sci 43:2345-2352

Chatfield C (1996) The analysis of time series data: an introduction. Chapman and Hall, New York

Chia FS, Buckland-Nicks J, Young CM (1984) Locomotion of marine invertebrate larvae: a review. Can J Zool 62: 1205-1222

Connell JH (1985) The consequences of variation in initial settlement vs. postsettlement mortality in rocky intertidal communities. J Exp Mar Biol Ecol 93:11-45

$>$ Dawirs RR (1985) Temperature and larval development of Carcinus maenas (Decapoda) in the laboratory; predictions of larval dynamics in the sea. Mar Ecol Prog Ser 24:297-302

DiBacco C, Sutton D, McConnico L (2001) Vertical migration behaviour and horizontal distribution of brachyuran larvae in a low-inflow estuary: implications for bay-ocean exchange. Mar Ecol Prog Ser 217:191-206

dos Santos A (1999) Larvas de crustáceos decápodes ao largo da costa Portuguesa. PhD dissertation, University of Lisbon, Lisbon

dos Santos A, González-Gordillo JI (2004) Illustrated keys for the identification of the Pleocyemata (Crustacea, Decapoda) zoeal stages, from the coastal region of southwestern Europe. J Mar Biol Assoc UK 84:205-227

dos Santos A, Lindley JA (2001) Crustacea, Decapoda: Larvae, II. Dendrobranchiata (Aristeidae, Benthesicymidae, Penaeidae, Solenoceridae, Sicyonidae, Sergestidae and Luciferidae). ICES Identif Leafl Plankton 186:1-9

dos Santos A, Calado R, Bartilotti C, Narciso L (2004) The larval development of the partner shrimp Periclimenes sagittifer (Norman, 1861) (Decapoda: Caridea: Palaemonidae: Pontoniinae) described from laboratory-reared material, with a note on chemical settlement cues. Helgoland Mar Res 58:129-139

dos Santos A, Santos AMP, Conway DVP (2007) Horizontal and vertical distribution of cirripede cyprid larvae in an upwelling system off the Portuguese coast. Mar Ecol Prog Ser 329:145-155

Epifanio CE, Garvine RW (2001) Larval transport on the Atlantic continental shelf of North America: a review. Estuar Coast Shelf Sci 52:51-77

> Forward R Jr, Rittschof D (1994) Photoresponses of crab megalopae in offshore and estuarine waters: implications for transport. J Exp Mar Biol Ecol 182:183-192

Forward R Jr, Frankel DAZ, Rittschof D (1994) Molting of megalopae from the blue crab Callinectes sapidus: effect of offshore and estuarine cues. Mar Ecol Prog Ser 113: $55-59$

> Garrison LP (1999) Vertical migration behavior and larval transport in brachyuran crabs. Mar Ecol Prog Ser 176: 103-113

González-Gordillo JI, dos Santos A, Rodríguez A (2001) Checklist and annotated bibliography of decapod Crustacea larvae from the southwestern European coast (Gibraltar Strait area). Sci Mar 65:275-305

$>$ Hobbs RC, Botsford LW (1992) Diel vertical migration and timing of metamorphosis of larvae of the Dungeness crab Cancer magister. Mar Biol 112:417-428

$>$ Lindley JA (1986) Vertical distributions of decapod crustacean larvae and pelagic post-larvae over Great Sole Bank (Celtic Sea) in June 1983. Mar Biol 90:545-549

Lindley JA, Williams R, Conway DVP (1994) Variability in dry weight and vertical distributions of decapod larvae in the Irish Sea and North Sea during the spring. Mar Biol 120:385-395

- Marta-Almeida M, Dubert J, Peliz A, Queiroga H (2006) Influence of vertical migration pattern on retention of crab larvae in a seasonal upwelling system. Mar Ecol Prog Ser 307:1-19

Mileikovsky SA (1973) Speed of active movement of pelagic larvae of marine bottom invertebrates and their ability to regulate their vertical position. Mar Biol 23:11-17

> Pearre S (2003) Eat and run? The hunger/ satiation hypothesis in vertical migration: history, evidence and consequences. Biol Rev Camb Philos Soc 78:1-79

> Peliz A, Rosa T, Santos AMP (2002) Jets, eddies and counterflows in the western Iberian upwelling system. J Mar Syst 35:61-77

Peliz A, Marchesiello P, Dubert J, Marta-Almeida M, Roy C, Queiroga H (2007) A study of crab larvae dispersal on the western Iberian shelf: physical processes. J Mar Syst 68: 215-236

Peterson W (1998) Life cycle strategies of copepods in coastal upwelling zones. J Mar Syst 15:313-326

Queiroga H (1996) Distribution and drift of the crab Carcinus maenas (L.) (Decapoda, Portunidae) larvae over the continental shelf off northern Portugal in April 1991. J Plankton Res 18:1981-2000

Queiroga H (1998) Vertical migration and selective tidal stream transport in the megalopa of the crab Carcinus maenas. Hydrobiologia 375-376:137-149

Queiroga H, Blanton JO (2005) Interactions between behaviour and physical forcing in the control of horizontal transport of decapod crustacean larvae. Adv Mar Biol 47: $107-214$

Queiroga H, Costlow JD Jr, Moreira MH (1997) Vertical migration of the crab Carcinus maenas first zoea in an estuary: implications for tidal stream transport. Mar Ecol Prog Ser 149:121-132

> Queiroga H, Almeida MJ, Alpuim T, Flores AAV and others (2006) Tide and wind control of megalopal supply to estuarine crab population on the Portuguese west coast. Mar Ecol Prog Ser 307:21-36 
Quinn GP, Keough MJ (2002) Experimental design and data analysis for biologists. Cambridge University Press, Cambridge

Rothlisberg PC, Pearcy WG (1977) An epibenthic sampler used to study the ontogeny of vertical migration of Pandalus jordani (Decapoda, Caridea). Fish Bull 74:994-997

Santos AMP, Peliz A, Dubert J, Oliveira PB, Angélico MM, Ré P (2004) Impact of a winter upwelling event on the distribution and transport of sardine eggs and larvae off western Iberia: a retention mechanism. Cont Shelf Res 24:149-165

Santos AMP, Ré P, Dos Santos A, Peliz A (2006) Vertical distribution of the European sardine (Sardina pilchardus) larvae and its implications for their survival. J Plankton Res 28:523-532

Shanks AL (1985) Behavioral basis of internal-wave-induced shoreward transport of megalopae of the crab Pachygrapsus crassipes. Mar Ecol Prog Ser 24:289-295

Shanks AL (1986) Vertical migration and cross-shelf dispersal of larval Cancer spp. and Randallia ornata (Crustacea: Brachyura) off the coast of southern California. Mar Biol 92:189-199

Shanks AL (1995) Mechanisms of cross-shelf dispersal of larval invertebrates and fish. In: McEdward L (ed) Ecology of marine invertebrate larvae. CRC Press, Boca Raton, FL, p 323-367

Shanks AL, Brink L (2005) Upwelling, downwelling, and cross-shelf transport of bivalve larvae: test of a hypothesis.

Editorial responsibility: Otto Kinne,

Oldendorf/Luhe, Germany
Mar Ecol Prog Ser 302:1-12

Shanks AL, Eckert GL (2005) Population persistence of California current fishes and benthic crustaceans: a marine drift paradox. Ecol Monogr 75:505-524

Stehle M, dos Santos A, Queiroga H (2007) Comparison of zooplankton sampling performance of Longhurst-Hardy Plankton Recorder and Bongo nets. J Plankton Res 29: 169-177

Tapia FJ, Pineda J, Ocampo-Torres FJ, Fuchs HL, Parnell PE, Montero P, Ramos S (2004) High-frenquency observations of wind-forced onshore transport at a coastal site in Baja California. Cont Shelf Res 24:1573-1585

Underwood AJ (1997) Experiments in ecology: Their logical design and interpretation using analysis of variance. Cambridge University Press, Cambridge

Underwood AJ, Fairweather PG (1989) Supply-side ecology and benthic marine assemblages. Trends Ecol Evol 4: $16-21$

UNESCO (1968) Zooplankton sampling. UNESCO, Paris

> Williams R, Collins NR, Conway DVP (1983) The double LHPR system, a high-speed micro- and macroplankton sampler. Deep-Sea Res 30:331-342

Wing SR, Botsford LW, Ralston SV, Largier JL (1998) Meroplanktonic distribution and circulation in a coastal retention zone of the northern California upwelling system. Limnol Oceanogr 43:1710-1721

Zariquiey-Álvarez R (1968) Crustáceos decápodos ibéricos. Invest Pesq (Spain) 32

Submitted: April 23, 2007; Accepted: November 19, 2007

Proofs received from author(s): April 4, 2008 